\title{
Are the Condition, Growth and Diet of Yellow Perch (Perca flavescens) Different between the Three Major Basins of Lake George, New York?
}

\author{
Brett D. D’Arco, Jeremy L. Farrell, Sandra A. Nierzwicki-Bauer and Charles W. Boylen
}

Darrin Fresh Water Institute and Department of Biological Sciences, Rensselaer Polytechnic Institute, 5060 Lake Shore Dr., Bolton Landing, NY 12814, USA

\begin{abstract}
Gill netting was carried out at 25 sites in Lake George, New York to determine if interbasin differences of yellow perch (Perca flavescens) exist. Fish relative weight, growth and diet were analyzed for 267 yellow perch. Yellow perch are known to be omnivorous in the lake eating zooplankton, benthos and small fishes in both the littoral and pelagic waters. The length-weight relationship exhibited a significant difference amongst the Narrows, North and South basins for condition constants $(\mathrm{p}<0.05)$. Relative weights were consistently found to be below the general target range and had significant differences between the basins. Growth models of fish caught in the three basins showed variation in growth of yellow perch. The yellow perch from the North basin exhibited allometric growth, while those in the South and Narrows displayed isometric growth. The diets of yellow perch between the basins also were found to be different. Previous studies have noted differences between the basins with respect to chlorophyll a, chemistry, and biota. This study provides evidence of differences in the fishery amongst the basins that follow similar, previously defined, differences in chemistry.
\end{abstract}

Keywords: Age, diet, growth, length-weight relationship, relative weight, yellow perch.

\section{INTRODUCTION}

Lake George, New York supports a two-tiered fishery with cold and warm water fishes. Yellow perch are known to be omnivorous, eating zooplankton, benthos and small fishes in both the littoral and pelagic waters [1]. With the recent discovery of two new aquatic invasive species, Asian clam (Corbicula fluminea) and spiny water flea (Bythotrephes longimanus) the fisheries can be greatly altered by changes in the food web [2].

Little attention has been given to yellow perch in Lake George in the last three decades. In the early 1920s yellow perch was considered the staple food fish, of the lake because it was caught year round. No management was recommended during this time as yellow perch were abundant [3]. The New York State Department of Environmental Conservation (NYSDEC) has collected yellow perch in lake trout (Salvelinus namaycush) studies from the 1960s to 1970s but no in depth analysis was done. A study carried out in November 1960 found high abundance of yellow perch caught at depths greater than 30 meters [4]. A summary of the findings of the NYSDEC fishing efforts found Lake George supported two strikingly different populations of lake trout between the North and South basin [5].

The relative weight and growth rate of fish have been analyzed in many studies to explain differences among populations [6-8]. Diet analysis has been used to assess differences and changes in fish communities [9-12]. Hayward and Margraf [10] observed differences in yellow perch

*Address correspondence to this author at the Darrin Fresh Water Institute and Department of Biological Sciences, Rensselaer Polytechnic Institute, 5060 Lake Shore Dr., Bolton Landing, NY 12814, USA; Tel: 518 644-3541; Fax: 518 644-3640; E-mail: nierzs@rpi.edu consumption rates among the basins of Lake Erie. These metrics are utilized to reveal interbasin differences of yellow perch in Lake George. This species was selected for this study because it is one of the key native forage fishes in the lake. The goals of the present study were to test the following hypotheses:

1) The health status of yellow perch as calculated by relative weight differs amongst the populations in each of the basins in Lake George, New York.

2) Dietary differences exist amongst the yellow perch populations in the basins of Lake George, New York.

\section{MATERIALS AND METHODOLOGY}

\section{Study Site}

Lake George is a $113 \mathrm{~km}^{2}$ meso-oligotrophic lake located in the southeast portion of the Adirondack Park, New York, U.S [13]. The lake basin was formed as the dropped portion of a horst and graben formation 400 million years ago. More recently, in the last 100,000 years repeated glacial scouring dammed two pre-glacial rivers [14]. Following the retreat of the Wisconsin glaciation 10,000 - 12,000 years ago, the current lake was formed having a North and South basin that is separated by the Narrows, a shallow central area of the lake dotted with islands. Lake George is long and slender with a north-northeasterly orientation for $51 \mathrm{~km}$ and an average width of approximately $2.3 \mathrm{~km}$ (Fig. 1). The mean depth in the South basin is $15.5 \mathrm{~m}$ and $20.5 \mathrm{~m}$ in the North basin [15]. Surface area in the South basin is $57.6 \mathrm{~km}^{2}$ while the North basin is $56.4 \mathrm{~km}^{2}$ [15]. Lake George's physical characteristics are provided in Table 1. 


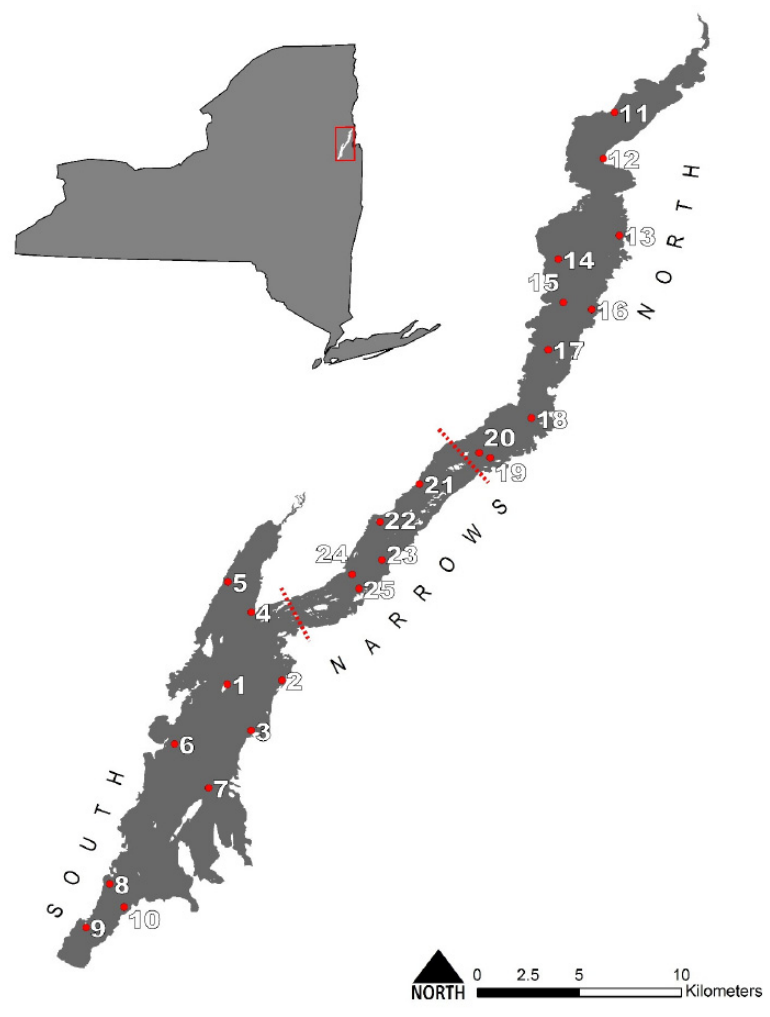

Fig. (1). Map of Lake George, New York showing the gill netting sites in the South (1-10), Narrows (21-25) and North (11-20) basins.

Table 1. Physical characteristics of the North and South basins of Lake George [15].

\begin{tabular}{|c|c|c|}
\hline Characteristic & $\begin{array}{c}\text { North Basin Including } \\
\text { the Narrows }\end{array}$ & South \\
\hline \hline Surface area $\left(\mathrm{km}^{2}\right)$ & 56.4 & 57.6 \\
\hline Maximum depth $(\mathrm{m})$ & 53.0 & 58.0 \\
\hline Mean depth $(\mathrm{m})$ & 20.5 & 15.5 \\
\hline Volume $\left(\mathrm{km}^{3}\right)$ & 1.1 & 1.0 \\
\hline Residence time $(\mathrm{yr})$ & 3.4 & 5.3 \\
\hline Watershed area $\left(\mathrm{km}^{2}\right)$ & 178.8 & 313.2 \\
\hline
\end{tabular}

\section{Field Sampling}

Gill net capture of fish was carried out in conjunction with the NYSDEC at 25 sites within Lake George (Fig. 1). Gill netting was conducted from May $28^{\text {th }}$ to June $5^{\text {th }}$ of 2013. Nets were deployed on consecutive nights for approximately a 23-hour set in the South (10 sites), Narrows (5 sites) and North (10 sites) basins. Each gang consisted of three 34 meter Swedish green-multifilament gill nets with 38-, 51- and 64-mm mesh sizes, respectively. One gang was set at each site at depths ranging from 6 to $47 \mathrm{~m}$.

Total length $(\mathrm{mm})$ and weight $(\mathrm{g})$ were recorded for each caught yellow perch, lake trout and cisco. At the first site, 63 yellow perch were measured and a limit of 25 was set per site after this point due to field processing time constraints. After physical measurements were recorded the fish were placed in coolers of ice to slow degradation of stomach contents. Yellow perch were frozen at $-20^{\circ} \mathrm{C}$ until further processing could be done.

\section{Age and Diet}

Otoliths were removed, cleaned and stored individually. Annuli were counted to determine the age of yellow perch. Sagitta of yellow perch were placed on a dark background immersed in distilled water and the age was determined using a dissecting microscope (10-50X magnification). Reflected light was used to view the annuli with a fiber optic light adapter attached to a halogen light with a goose neck.

Stomachs were removed from thawed yellow perch placed in a plastic bag with $10 \%$ ethanol, labeled and stored at $-20^{\circ} \mathrm{C}$. Thawed stomachs had their contents rinsed into a petri dish with distilled water and identified to species level where possible. Organisms found were categorized by prey groups. The prey items used were clam, crustacean, fish, insect, plant material, snail and zooplankton. The frequency of occurrence and enumeration analyses was used for diet determination of yellow perch.

\section{Data Analysis}

All statistical analysis methods were chosen a priori to avoid biasing during data analysis. Statistical analyses were all conducted with $\alpha=0.05$. All data were tested for normality using a skewness test $(\mathrm{p}>0.05)$.

Catch per unit effort (CPUE) was calculated for each site and the mean calculated per basin for each species. One-way analysis of variance (ANOVA) was performed on the CPUE across the basins. Bayesian multi-comparison was used to test for differences amongst the groups.

The length-weight relationship was calculated for yellow perch [16]. The slope of the length-weight regression, $b$, was then compared to a value of 3 to determine growth type (isometric or allometric). It was also compared between basins via analysis of covariance (ANCOVA) to determine differences between the regressions.

Relative weight was used as the metric for determining the condition of the fish communities in Lake George. The relative weight of fish was found by the equation developed in 1991 by Murphy et al. [17]. Yellow perch standard weight equation was developed in 1991 by Willis et al. [18]. The minimum length for the use of this equation is $100 \mathrm{~mm}$. Relative weights above 200 are considered abnormally high and were removed from analysis. One-way ANOVA was performed on mean $\mathrm{W}_{\mathrm{r}}$ across the basins. Linear regression for each basin was calculated for $\mathrm{W}_{\mathrm{r}}$ versus age. The von Bertalanffy growth model (VBGM) was used to determine fish growth [16].

Mean percent count for each prey item was calculated in the South, Narrows and North basins. One-way ANOVA was conducted on each prey item across the basins. The diet overlap of yellow perch between basins was calculated using the Schoener Index $(S)$ [19]. $S$ values greater than 0.6 are considered to have similar overlap [20]. 


\section{RESULTS}

Seven hundred forty-seven yellow perch were caught representing $73.1 \%$ of the total catch. Yellow perch caught at all 10 sites in the South basin totaled 609 fish in 219.00 hours (CPUE 2.78 fish/hr). In 105.76 hours of effort 76 yellow perch were collected from 5 sites with a CPUE of $0.72 \mathrm{fish} / \mathrm{hr}$ in the Narrows basin. In 212.65 hours of effort 62 yellow perch were collected from 10 sites with a CPUE of $0.29 \mathrm{fish} / \mathrm{hr}$ in the North basin. One-way ANOVA between the basins revealed a significant difference in CPUE for yellow perch $(\mathrm{p}<0.05$, df $=2$ and $22, \mathrm{n}=25, \mathrm{~F}=4.80$; Table 2).

Table 2. One-way ANOVA on mean catch per unit effort (fish/hr) in the South, Narrows and North basins are shown for yellow perch. Different lettering indicates significant difference $(\mathrm{p}<\mathbf{0 . 0 5})$.

\begin{tabular}{|c|c|c|c|}
\hline Basin & CPUE & $\begin{array}{c}\text { 95\% Confi- } \\
\text { dence Interval }\end{array}$ & Significance \\
\hline \hline South & 2.78 & \pm 1.19 & $\mathrm{a}$ \\
\hline Narrows & 0.72 & \pm 1.58 & $\mathrm{a}, \mathrm{b}$ \\
\hline North & 0.29 & \pm 1.19 & $\mathrm{~b}$ \\
\hline
\end{tabular}

\section{Growth}

The number of fish caught and average size of each age class was determined by otolith annuli counting (Table 3). Length-weight relationships were $W=1.8^{-6} L^{3.3}$, $W=7.3^{-10} L^{4.7}$ and $W=1.6^{-5} L^{2.91}$ in the South, Narrows and North basins, respectively (Fig. 2). The slopes (b) of the length-weight regression were significantly different between all basins as determined by ANCOVA $(\mathrm{p}<0.05$, $\mathrm{df}=$ 2 and $247, n=253 \mathrm{~F}=39.9$ ). The condition constant (b) in the South basin was not significantly different from 3 indicating isometric growth $(\mathrm{p}>0.05, \mathrm{~T}=-1.1)$. The condition constant (b) in the North basin was significantly greater than 3 indicating allometric growth $(\mathrm{p}<0.05, \mathrm{~T}=6.4)$. The con- dition constant (b) was not significantly different from 3 in the Narrows basin indicating isometric growth $(\mathrm{p}>0.05, \mathrm{~T}=$ 1.8). A von Bertalanffy growth model was used to estimate growth and produced $L_{\infty}=343 \mathrm{~mm}, K=-0.24, t_{0}=-1.45$ in the South basin, $L_{\infty}=317 \mathrm{~mm}, K=-0.32, t_{0}=-1.10$ in the Narrows basin and $L_{\infty}=345 \mathrm{~mm}, K=-0.17, t_{0}=-2.04$ in the North basin.

\section{Relative Weight}

Relative weight $\left(\mathrm{W}_{\mathrm{r}}\right)$ ranged from $41-110$ with a mean of 73 in the South basin. The Narrows, $W_{\mathrm{r}}$, ranged from 38 124 with a mean of 66 . The North basin $\mathrm{W}_{\mathrm{r}}$ ranged from $15-$ 80 with a mean of 53. Two hundred twelve yellow perch were aged: 118, 37 and 57 from the South, Narrows and North basins, respectively. Yellow perch ages in the South, Narrows and North basins ranged from $1-9$ with a median of 3, 3 and 4, respectively. One-way ANOVA indicates a significant difference amongst the basins for mean $\mathrm{W}_{\mathrm{r}}(\mathrm{p}<$ $0.05, \mathrm{df}=2$ and 209, $\mathrm{n}=212, \mathrm{~F}=29.9$ ). Linear regressions were found to be significant for the South and North basins for $\mathrm{W}_{\mathrm{r}}$ versus age (South: $\mathrm{p}<0.05, \mathrm{df}=1$ and $116, \mathrm{n}=118$, $\mathrm{F}=12.98$; North: $\mathrm{p}<0.05, \mathrm{df}=1$ and $55, \mathrm{n}=57, \mathrm{~F}=16.67$; Fig. 3).

\section{Diet Overlap}

A total of 218 yellow perch stomach contents were analyzed. In the South basin, 70\% (84) of 120 stomachs contained food. Yellow perch from the Narrows basin had $64.9 \%$ (24) of 37 stomachs with food. For the North basin $44.2 \%$ (27) of 61 stomachs were not empty. The most frequent prey categories were insects, clams and zooplankton in the South, Narrows and North basins, respectively (Table 4). In the North and South basins zooplankton was the highest in numerical abundance (Table 4). A Schoener index of 56\% for yellow perch between the basins did not show similar diet overlap (Fig. 4). Mean percent count was significantly different between the South, Narrows and North basins for the clam prey items $(\mathrm{p}<0.05, \mathrm{df}=2$ and $132, \mathrm{n}=135, \mathrm{~F}=$ 8.1). Zooplankton prey items had a significant difference

Table 3. Average length in mm and number for yellow perch age classes in the South, Narrows and North basins of Lake George.

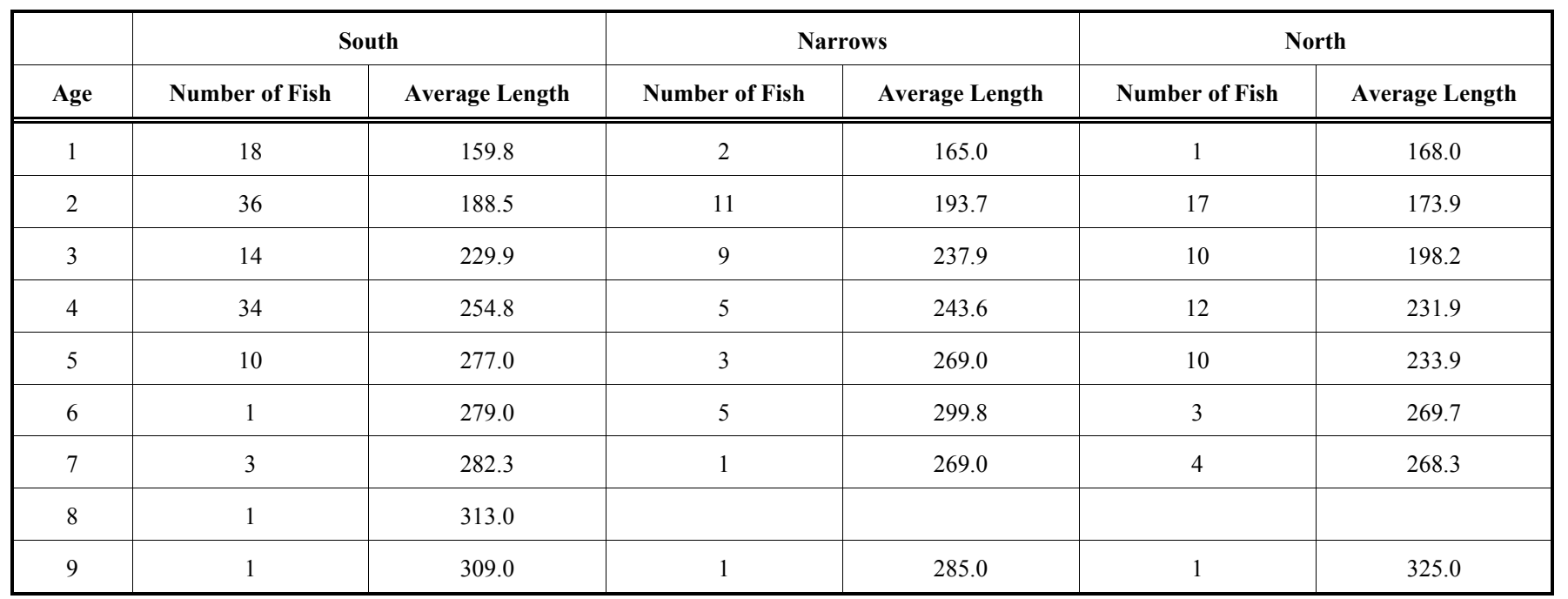



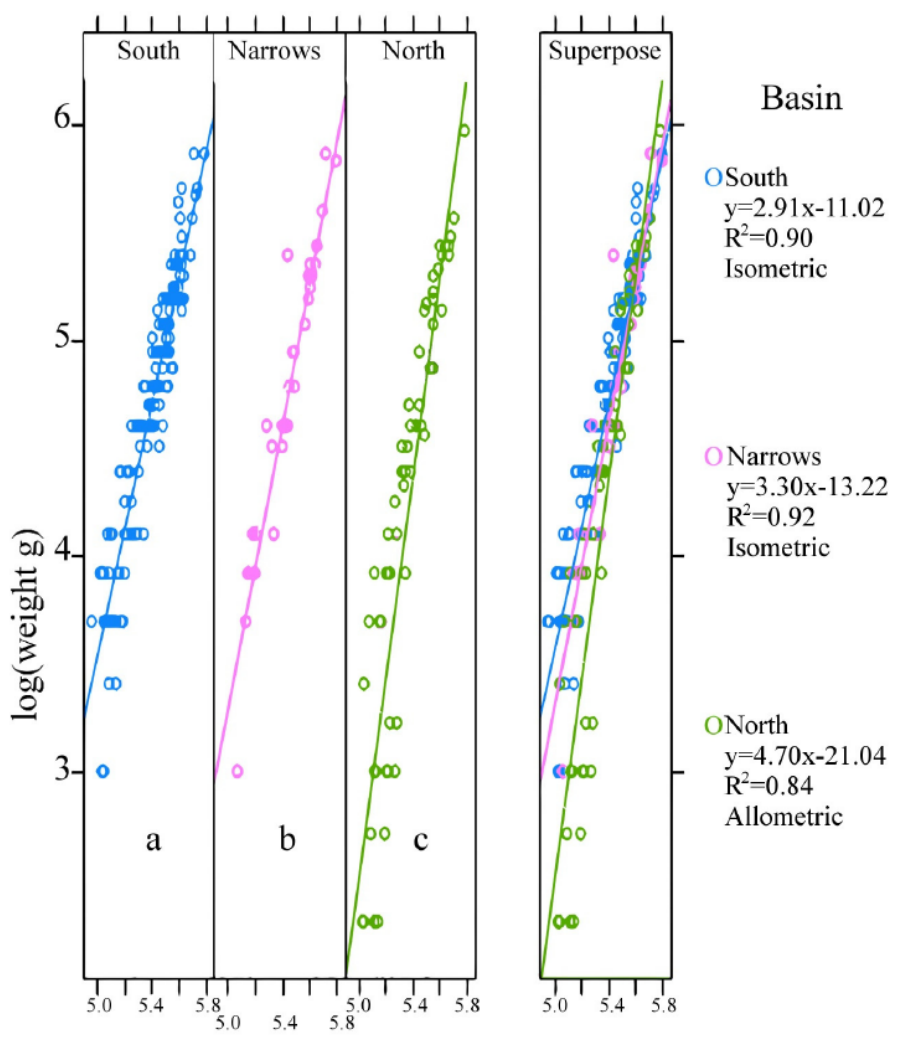

$\log ($ total length $\mathrm{mm})$

Fig. (2). Length-weight relationship of yellow perch in the South, Narrows and North basins. Groups with different lettering (a,b,c) indicates significant difference $(\mathrm{p}<0.05)$.

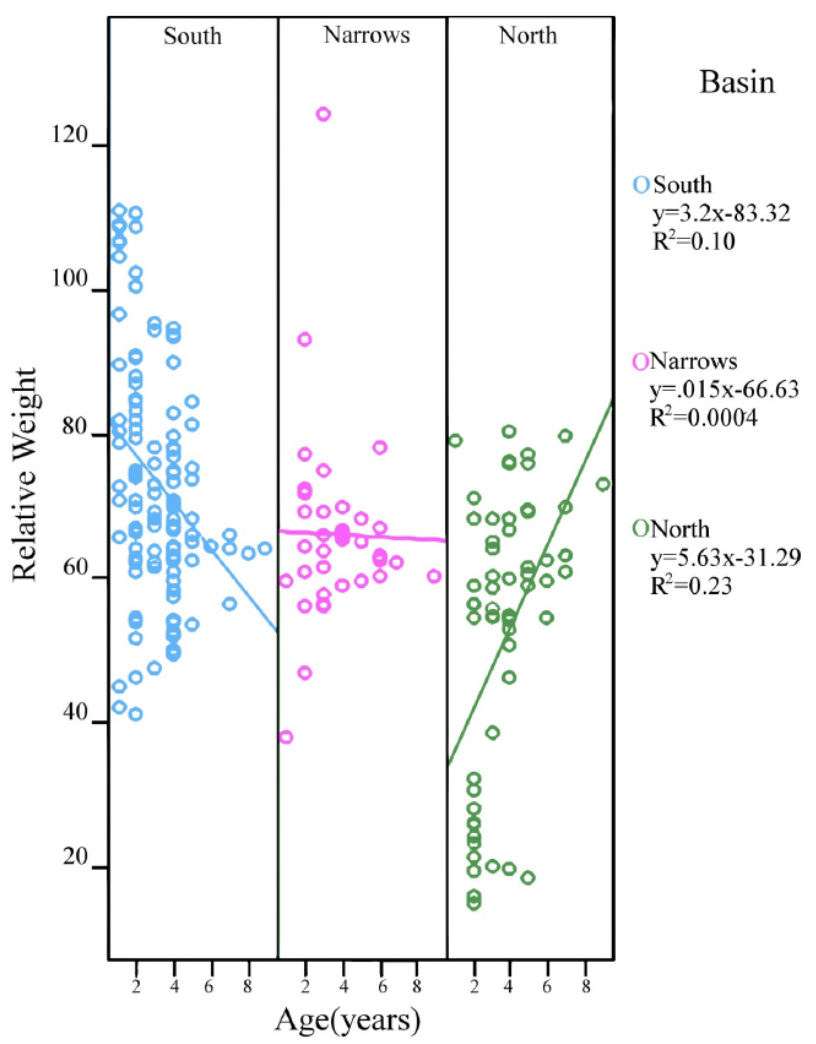

Fig. (3). Linear regression on $\mathrm{W}_{\mathrm{r}}$ vs age of yellow perch for the South, Narrows and North basins. 
Table 4. Frequency of occurrence $(\% \mathrm{~F})$ and numerical abundance $(\% \mathrm{~N})$ of prey categories in the South, Narrows and North basins of Lake George for yellow perch.

\begin{tabular}{|c|c|c|c|c|c|c|}
\hline Food Item & \multicolumn{2}{|c|}{ South } & \multicolumn{2}{|c|}{ Narrows } & \multicolumn{2}{|c|}{ North } \\
\hline Crustaceans & 33.30 & 10.90 & 29.20 & 3.63 & 3.70 & 0.10 \\
\hline Fish & 1.20 & 0.27 & 4.20 & 0.16 & 3.70 & 0.10 \\
\hline Miscellaneous & 6.00 & 0.30 & 0.00 & 0.00 & 7.40 & 0.10 \\
\hline Plant Materials & 15.5 & 2.29 & 20.80 & 1.66 & 0.00 & 0.00 \\
\hline Snails & 32.10 & 6.59 & 50.00 & 7.36 & 11.10 & 0.57 \\
\hline Zooplankton & 33.30 & 58.73 & 20.80 & 31.92 & 51.90 & 78.75 \\
\hline
\end{tabular}

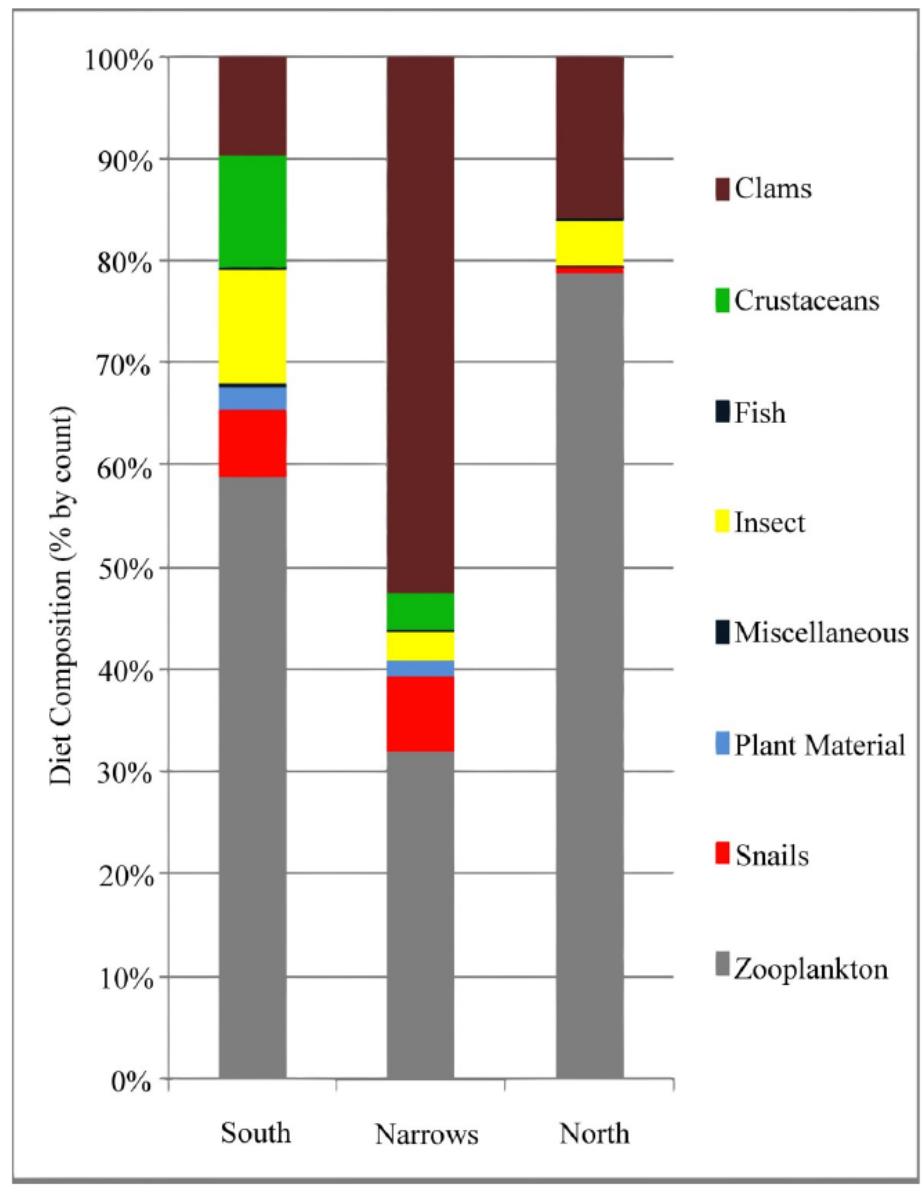

Fig. (4). Percent count composition of prey items in the South, Narrows and North basins for yellow perch.

between the basins $(\mathrm{p}<0.05, \mathrm{df}=2$ and $132, \mathrm{n}=135, \mathrm{~F}=$ 3.7). Sphaeriidae were the only clam species found in the stomachs of yellow perch. Caecidotea, an isopod, was the most abundant in the crustacean prey category. Chironomidae was the most abundant insect prey in the South basin and Trichoptera in the Narrows and North basins. Valvata was the most abundant snail prey throughout the basins and not previously identified in Lake George.

\section{DISCUSSION}

The importance of yellow perch in Lake George has long been noted for over 100 years. In the early 1900s the species were fished commercially in the Lake [21]. The yellow perch in the lake has been studied occasionally for the last century in the context of the entire fishery $[3,22]$. In the 1970s yellow perch were considered the most abundant species with 
an estimate of 2-4 million individuals in the lake [1]. The fish are still culturally and financially important yet no survey had been conducted in the last several decades [23]. This study has attempted to examine the current status of this fish in an effort to understand the relationship they have with the Lake and its chemically distinct basins.

The South basin had a higher CPUE of yellow perch, possibly indicating a population size difference between the basins. A difference in habitat between the basins is a probable cause of this abundance difference; however, it is also possible that the CPUE was influenced due to juvenile lake trout being targeted during the study.

In Lake George the length-weight relationship showed significant differences for yellow perch amongst the basins in condition constants (b). Fish from the Narrows and South basins exhibited isometric growth revealed by the lengthweight relationship which is found to be a rare occurrence in most fishes [24-26]. However, yellow perch in the North basin are heavier at greater lengths. Yellow perch exhibited slight variation in growth between the South, Narrows and North basins. Yellow perch from the South and Narrows basins showed very similar growth characteristics but were substantially different from growth in the North basin. The North basin yellow perch exhibited the highest theoretical maximum length $\left(\mathrm{L}_{\infty}\right)$ as confirmed by local fisherman. By comparison, in Lake Erie, growth rate differences in yellow perch between the basins of the lake have also been found [10]. It was hypothesized that these growth differences were due to food consumption differences within the basins which is also a prospective explanation for the observed results in Lake George. These characteristics have also been reported in Lake Champlain most notably between the northern and southern regions [27].

Relative weights were all found to be below the general target range of 95 to 105 and exhibited significant differences among the basins [28]. As yellow perch in the South basin age, their relative weight decreases while North basin relative weight increases with age. These relative weight differences may be caused by the different environmental factors within Lake George including chemical and biological differences [13, 29-33].

The fish diets between the North and South basins in Lake George did not show substantial overlap indicating that yellow perch consume different prey in the three basins. Clams were present in all of the fish stomachs in the North and South basins. In the Narrows an equal amount of clams, insects and snails were present in more than half the stomachs. This could be an indication that clams dominate the benthic community throughout Lake George. Yellow perch exhibited low preference for fish amongst all the basins. Insects were frequently found in stomachs but were in low abundance; this may indicate high availability but low preference as a food source. Zooplankton dominated diet numerical abundance in the North and South basins while clams dominated in the Narrows. A significantly higher percent count of clams was consumed by yellow perch in the North and Narrows basins than the South basin. The differences in consumption of clams and insects may be an indication of different benthic communities between the basins.
Chemical and biological differences have been known between the basins for decades [13, 29-33]. These bio- geochemical dissimilarities are likely contributors of the existing differences found in the yellow perch community. A chemical gradient is present in Lake George in which salt, phosphorus and chlorophyll decrease in concentration while water clarity increases from South to North [30]. Total phosphorus concentrations in the South basin were reported at $5.14 \mu \mathrm{gL}^{-1}$ and in the North basin $3.64 \mu \mathrm{gL}^{-1}$ representing a $41 \%$ decline [30]. Recent statistical analysis of the 30 -year Boylen et al. dataset [30] shows clear chemical differences in Lake George water chemistry between the North and South basins of the lake [34]. It has been noted that biota, specifically the diatoms, are shifting to a community similar to a more eutrophic lake. As published several decades ago, planktonic and periphytic diatom population changes in Lake George appear to correlate with environmental parameters [29]. Siegfried [33] concluded the zooplankton differences between the North and South basins could be due to the introduction of rainbow smelt. Biological and chemical differences may play a role in the population dynamics of the fishes in Lake George. It has been further speculated that top down feeding preferences could contribute to the explanation of why there are differences in phytoplankton and zooplankton community structure between the basins [31]. Temporal and spatial patterns of water chemistry using cluster analysis for spring and summer showed two distinct basins within Lake George in the 1980s and early 1990s [13].

Yellow perch have demonstrated subtle but distinct genetic drift across Northern temperate lakes related to the refugia they inhabited during glacial advances and retreats [35]. Lake George currently occupies a basin that previously drained into the Hudson River in the southern basin and into Lake Champlain from the Northern basin until the last ice age scoured and deposited material to form one Lake that flows to the North. A population genetic study by SepuvedaVillet and Stepein [35] indicates separate haplotypes for Lake Champlain and the Hudson River. Since Lake George is on the edge of these two watersheds and there are distinct growth, populations and feeding differences amongst the fish within the Lake, it is possible that Lake George represents a location with both haplotypes or a mixture of the two. A follow-up genetic analysis of yellow perch in Lake George could help resolve the population differences observed herein.

While the causes of these growth, relative weight, catch and diet differences are not completely understood, it is common in large lakes for aggregations of yellow perch to exhibit different growth characteristics [36]. It is hypothesized that differences in relative weight and growth may be due to a difference in prey consumption for yellow perch. The differences in consumption of clams and zooplankton for yellow perch may be an indication of different benthic communities between the basins. These dietary findings may explain the differences found in their relative weight and growth characteristics. In future studies, use of the dry weight diet analysis would be beneficial so that energetics and consumption rates can be determined, which may also help to explain the differences found in the relative weights of the fish. Studying the chemical influences and dietary energetics of yellow perch as well as other fishes, may lead 
to a better understanding of the existing relative weight, growth and diet differences within Lake George.

\section{CONFLICT OF INTEREST}

The authors confirm that this article content has no conflict of interest.

\section{ACKNOWLEDGEMENTS}

We are grateful for partial funding for this research by the Helen V. Froehlich Foundation. We thank Jim Pinheiro and Rob Fiorentino and staff of the New York State Department of Environmental Conservation for providing the equipment and personnel to conduct a fishery survey of Lake George. Also, we wish to acknowledge the staff and students of the Darrin Fresh Water Institute who have assisted in the completion of this study and to Brian Keleher for his graphic editing.

\section{REFERENCES}

[1] George C. The fishes of the lake george watershed. In: Boylen CW, Ed. The Lake George Ecosystem: Proceedings of the Lake George research symposium. Lake George, NY. The Lake George Association 1981.

[2] Anthony SJ. Lake George aquatic invasive species prevention plan and generic environmental impact statement. Lake George (NY). Lake George Park Commission (US) 2013 Dec. p. 244.

[3] Needham JG, Sibley CK, Juday C, Moore E, Titcomb JW. Biological survey of Lake George, N.Y. Albany (NY). New York State Conservation Commission (US) 1922.

[4] Neth PC. Lake George lake trout investigation. Albany (NY). New York State Department of Environmental Conservation (US) 1960.

[5] Lantiegne EL. Lake George salmonid investigations, 1975 Progress Report. Mimeograph. Albany, NY. New York State Department of Environmental Conservation 1977.

[6] Wynn KH. Fish-community assessment in gore creek, Colorado, 1998. Denver (CO). U.S. Geology Survey (US) 1999 Dec. p. 6.

[7] Downen MR, Mueller KW. 1998 Twin Lakes (Gissburg Ponds) Survey: Assessment and comparison of the warmwater fish. la Conner (WA). Washington Department of Fish and Wildlife (US) 2000.

[8] Wilberg MJ, Bence JR, Eggold BT, Makauskas D, Clapp DF. Yellow perch dynamics in southwestern Lake Michigan during 1986 and 2002. N Am J Fish Manage 2005; 25: 1130-52.

[9] Elrod JH, O'Gorman R. Diet of juvenile lake trout in southern Lake Ontario in relation to abundance and size of prey fishes, 19791987. Trans Am Fish Soc 1991; 120: 290-302.

[10] Hayward RS, Margraf FJ. Eutrophication effects on prey size and food available to yellow perch in Lake Erie. Trans Am Fish Soc 1987; 116: 210-23.

[11] Teixeira A, Cortes RMV. Diet of stocked and wild trout, Salmo trutta: is there competition for resources? Folia Zool 2006; 55: 6173.

[12] Winfield IJ, James JB, Fletcher JM. Northern pike (Esox lucius) in a warming lake: changes in population size and individual condition in relation to prey abundance. Hydrobiologia 2008; 601: 2940.

[13] Momen B, Eichler LW, Boylen CW, Zehr JP. Application of multivariate statistics in detecting temporal and spatial patterns of water chemistry in Lake George, New York. Ecol Modell 1996; 91: 183-92.

[14] Wright GF. Glacial phenomena between Lake Champlain, Lake George and Hudson River. Science 1895; 2: 673-8.
[15] Langmuir I (Posth.), Scott JT, Walter EG, Stewart R, Roson WX. Langmuir circulations and internal waves in Lake George. Albany (NY): University of New York (US) 1966, p. 36.

[16] Ricker WE. Computation and interpretation of biological statistics of fish populations. J Fish Res Board Can 1975; 191: 382.

[17] Murphy BR, Willis DW, Springer TA. The relative weight index in fisheries management: status and needs. Fisheries 1991; 16: 30-8.

[18] Willis DW, Guy CS, Murphy BR. Development and evaluation of a standard weight (Ws) equation for yellow perch. N Am J Fish Manage 1991; 11: 374-80.

[19] Schoener TW. Nonsynchronous spatial overlap of lizards in patchy habitats. Ecology 1970; 51: 408-18.

[20] Wallace RK. An assessment of diet-overlap indexes. Trans Am Fish Soc 1981; 110: 72-6.

[21] US Bureau of Fisheries. Report of the commissioner of fisheries to the secretary of commerce and labor. washington, DC: US Government Printing Office 1905, p. 612.

[22] Pfeiffer MH. Lake George lake trout nvestigations. A summary of cotton mesh gill netting in 1966. Albany (NY). New York State Department of Environmental Conservation (US) 1966.

[23] Connelly NA, Brown TL. New York Statewide angler survey 2007 report 1: Angler effort and expenditures. Albany (NY). New York State Department of Environmental Conservation (US) 2009, p. 109.

[24] Le Cran ED. The length-weight relationship and seasonal cycle in gonad weight and condition in the perch (Perca fluviatilis). J Anim Ecol 1951; 20: 201-19.

[25] McGurk MD. Effects of net capture on the postpreservation morphometry, dry weight and condition factor of Pacific herring larvae. Trans Am Fish Soc 1985; 114: 348-55.

[26] Bolger T, Connolly PL. The selection of suitable indices for the measurement and analysis of fish condition. J Fish Biol 1989; 34: 171-82.

[27] Fisheries Technical Committee, Strategic plan for lake champlain fisheries. Essex Junction (VT). Lake Champlain Fish and Wildlife Management Cooperative, USFWS (US) 2009.

[28] Blackwell BG, Brown ML, Willis DW. Relative weight $\left(\mathrm{W}_{\mathrm{r}}\right)$ status and current use in fisheries assessment and management. Rev Fish Sci 2000; 8: 1-44.

[29] Williams DL, Clesceri NL. Diatom populations changes in Lake George, N.Y. Office of water resources research (NY): Rensselaer Polytechnic Institute (US) 1972 Contract No. 14-31-0001-3387.

[30] Boylen C, Eichler L, Swinton M, et al. The state of the lake: Thirty years of water quality monitoring on Lake George, New York, 1980 - 2009. Lake George (NY). The fund for Lake George (US) 2014, p. 72.

[31] Siegfried CA. Phytoplankton of Lake George: seasonal and geographic patterns. In: Boylen CW, Ed. The Lake George ecosystem: Proceedings of the Lake George research symposium. Lake George, NY. The Lake George Association 1981.

[32] Siegfried CA. Dynamics of the crustacean zooplankton of Lake George; or, there's a rainbow over Lake George but where's the pot of gold. In: Boylen CW, Ed. The Lake George ecosystem: Proceedings of the Lake George research symposium. Lake George, NY. The Lake George Association 1983.

[33] Siegfried CA. Large-bodied crustacean and rainbow smelt in Lake George, New York: Trophic interactions and phytoplankton community composition. J Plankton Res 1987; 9: 27-39.

[34] Michelena TM, Farrell JL, Eichler LW, Boylen CW. Distribution and cycling of chemical constituents in the pelagic zone of Lake George, NY: two lakes instead of one. Northeast Geosci 2015; (in press).

[35] Sepuveda-Villet OJ, Stepein CA. Waterscape genetics of the yellow perch (Perca flavescens): patterns across large connected ecosystems and isolated relict populations. Mol Ecol 2012; 21: 5795826.

[36] Forney J, Rudstam LG, Green DM, Stang DL. Percid sampling manual, chapter 3. In: Fish sampling manual, guidelines for the collection, analyses and interpretation of fisheries data by units of the NYSDEC. Albany, NY. Division of Fish and Wildlife 1994. 